\title{
ANTIATHEROSCLEROTIC AND LIPID LOWERING EFFECTS OF CINNAMOMUM VERUM IN CHOLESTEROL-FED RABBITS
}

\author{
SURESH C. JOSHI, PRATIBHA K. JAIN, PRIYANKA SHARMA
}

Reproductive Toxicology Unit, Center for advanced studies, Department of Zoology, University of Rajasthan, Jaipur 302055 India Email: s_c_joshi2003@rediffmail.com

Received: 27 Sep 2016, Revised and Accepted: 25 Nov 2016

\section{ABSTRACT}

Objective: The present study was designed to investigate the antihyperlipidemic and anti-atherosclerotic activity of $70 \%$ methanolic crude extract of Cinnamomum verum bark in high cholesterol-fed diet rabbits.

Methods: $C$. verum extract was administered at a dose level of $200 \mathrm{mg} / \mathrm{kg}$ and $300 \mathrm{mg} / \mathrm{kg}$ (p. o) daily for $120 \mathrm{~d}$ to cholesterol-fed rabbits. Lipid profile in serum and histological changes in heart and aorta were investigated. The statistical analysis was carried out by student's ' $t$ ' test.

Results: Plant extract showed a significant decrease in the levels of serum total cholesterol, triglycerides, phospholipids, LDL, VLDL (P $\leq$ 0.001) in a dose-dependent manner in treated animals. HDL ratio improved overwhelmingly as well as the marked decline was also noticed in the atherogenic index after administration with $C$. verum extract. Histopathological examinations demonstrated less cholesterol deposits in the aorta and significant increase in lumen size of coronary arteries of high cholesterol diet animals given $C$. verum compared to the high cholesterol diet animals not given $C$. verum supplement.

Conclusion: The phytochemical analysis of methanol extracts indicated a strong presence of alkaloids, flavonoids, tannins, phenols, saponins and fatty acids may be responsible for the significant hypolipidaemic as well as antiatherosclerotic activity. Our study exhibited that the methanol extract of $C$. verum bark is a potent hypolipidaemic agent and decreased cholesterol deposition in the aorta and plaque formation process in the coronary artery of high cholesterol diet animals.

Keywords: Cinnamomum verum, Atherosclerosis, Hyperlipidaemic, Phytoconstituents, Cholesterol, Methanolic extract

(C) 2016 The Authors. Published by Innovare Academic Sciences Pvt Ltd. This is an open access article under the CC BY license (http://creativecommons.org/licenses/by/4.0/) DOI: http://dx.doi.org/10.22159/ijcpr.2017v9i1.16618

\section{INTRODUCTION}

In the face of unremitting advances in therapeutic interventional and surgical therapies for the treatment of atherosclerotic coronary disease the later remains the principal killer in the western and the developing world [1]. Dyslipidemia and resultant atherosclerosis are believed to stem from the imbalance of the lipid metabolites in the affected organism. Hyperlipidemia (mainly increased level of total cholesterol (TC), triglycerides (TG) and low-density lipoprotein (LDL) cholesterol along with decrease in high-density lipoprotein (HDL) cholesterol) contributes significantly to the manifestation and development of atherosclerosis and coronary heart diseases (CHDs) [2].

Atherosclerosis is the preliminary lipid disorders that affect large and medium-sized muscular arteries and is characterised by endothelial dysfunction, vascular inflammation, and the buildup of lipids, cholesterol, calcium, and cellular debris within the intima of the vessel wall. This buildup results in plaque formation, vascular remodelling, acute and chronic luminal obstruction, abnormalities of blood flow and diminished oxygen supply to target organs [3]. It is generally established that oxidative stress is strongly related to atherogenesis [4]. An antioxidant which inhibits oxidation of LDL should be effective for suppressing atherosclerosis [5].

Spices recommend a cheap but rich source of a number of micronutrients and other phytochemicals which help to prevent the progression of atherosclerosis [6, 7]. Botanical dietary supplements (herbs) can ameliorate this process and prevent cardiovascular disease at many steps in the process [8]. Cinnamon is the evergreen tree of the tropical area, a member of family Lauraceae, has been used in day to day routine as a spice. The extensive exploration of literature revealed that Cinnamomum verum is an imperative basis of various pharmacologically and medicinally significant chemicals, such as it mainly contains essential oils and important compounds like Cinnamaldehyde, eugenol, cinnamic acid and cinnamate, Cinnamic acid, Hydroxyl Cinnamaldehyde, Cinnamyl alcohol, Coumarin, Cinnamyl acetate, Borneol, etc [9].
It has got good anti-inflammatory [10], anti-oxidant [11], antiobesity [12], anti-microbial [13], Anticancer [14], and many other activities. It has been found to be extremely helpful in the treatment of Type 2 diabetes mellitus [15] and insulin resistance. With this background information, the present study is undertaken to screen this commonly used spice cinnamon principally, for its ability to decrease lipid levels and oxidative stress in rabbits, fed high-fat diet.

\section{MATERIALS AND METHODS}

\section{Collection and extraction of plant material}

The authentic bark of Cinnamomum verum (Dalchini) was obtained from the National Institute of Ayurveda, Jaipur. The bark was powdered and soaked in $70 \%$ methanol for $24 \mathrm{~h}$ then the material was soxhleted for $72 \mathrm{~h}$. After this extraction solvent was removed under reduced pressure and controlled temperature $\left(55-60{ }^{\circ} \mathrm{C}\right)$ and dried to obtain a solid brown mass. This $70 \%$ methanolic crude extract of the $C$. verum was dissolved in distilled water and administered to the animals via oral gavage.

\section{Animal model}

New Zealand white male rabbits weighing 1.50-2.0 kg and age of 10-18 mo were used in the study. Animals were procured from Central Sheep and Wool Research Institute (CSWRI), Avika Nagar, Rajasthan. The animals were acclimatised for $10 \mathrm{~d}$ before being used for the experiments. The animals were grouped and housed in polypropylene cages at constant temperature and also maintained under a standard diet (Ashirwad Industrial Ltd., Punjab) and green leafy vegetables and water ad libitum. The experimental protocol was approved by Institutional Animal Ethical Committee (IAEC) and was executed according to the guidelines of Committee for the Purpose of Control and Supervision on Experiments on Animals (CPCSEA), India.

\section{Experimental design}

The rabbits were divided into following groups of six animals in each: 
Group I: Control-Placebo-treated $120 \mathrm{~d}$. (Vehicle treated)

Group II: Atherodiet+cholesterol feeding for $120 \mathrm{~d}$

Group III: Atherodiet+cholesterol feeding $+200 \mathrm{mg} / \mathrm{kg} \mathrm{b}$. wt./day $C$. verum extract from day 1-120. (Concurrent treatment)

Group IV: Atherodiet+cholesterol feeding $+300 \mathrm{mg} / \mathrm{kg}$ b. wt./day $C$. verum extract from day 1-120. (Concurrent treatment)

Cholesterol feeding: $500 \mathrm{mg}$ cholesterol/kg. b. wt./rabbit/day in 5 ml coconut oil

The animal was sacrificed after completion of treatment, blood and tissue were taken out for biological and histological examinations.

\section{Induction of hyperlipidaemia}

Hyperlipidaemia was induced in New Zealand white male rabbits by daily oral administration of $500 \mathrm{mg}$ cholesterol/kg. b. wt./rabbit/ day in $5 \mathrm{ml}$ coconut oil

\section{Autopsy}

Animals were autopsied under ether anaesthesia after completion of $120 \mathrm{~d}$ of treatment. The blood was collected by cardiac puncture; serum was separated by centrifugation after $30 \mathrm{~min}$ and stored at$20{ }^{\circ} \mathrm{C}$ for biochemical analysis.

\section{Fixiation}

Heart and aorta (2-3 cm length) were quickly removed, cleared off the fat and connective tissue weighed on an electronic balance. A small section of heart and aorta of each animal was soaked in a $10 \%$ $(\mathrm{v} / \mathrm{v})$ formocalcium solution for $\mathrm{H}$ and $\mathrm{E}$ staining. The heart and aorta were processed for the normal histological section. The tissue samples were ultra-sectioned (5-6 $\mu \mathrm{m}$ thickness), stained with haematoxylin and eosin (HandE) and examined under a light microscope for observation of structural abnormality.

\section{Biochemical analysis}

The serum was assayed for total cholesterol [16], triglycerides [17], phospholipids [18], high density lipoprotein (HDL) [19], low-density lipoprotein (LDL) [20], very low-density lipoprotein (VLDL) [20] and total protein [21].

HDL Ratio [22] was determined as:

HDL Cholesterol X 100

Total Cholesterol -HDL Cholesterol

Atherogenic Index was derived using the formula-

$\underline{\text { LDL-Cholesterol + VLDL Cholesterol }}$ HDL Cholesterol

Deviation Percent was calculated as

$$
\frac{\text { Final value - Initial value }}{\text { Initial Value }} \times 100
$$

\section{Statistical analysis}

Data were represented as mean \pm SEM. The differences were compared for statistical significance by "t-test" by using SPSS software (16.0 version), and they were considered non-significant at $\mathrm{P} \leq 0.05$, significant at $\mathrm{P} \leq 0.01$ and highly significant at $\mathrm{P} \leq 0.001$.

\section{RESULTS}

\section{Antihyperlipidaemic parameters}

Effect of C. verum crude extract on total cholesterol (mg/dl)

As table 1 illustrated that rabbits fed on high cholesterol diet for 120 d caused a 9.8 fold increase in the concentration of serum total cholesterol level as compared to control. Concurrent treatment group showed the reduction by- $64.25 \%$ and $-71.63 \%$ at $200 \mathrm{mg}$ and $300 \mathrm{mg} / \mathrm{kg}$ b. wt./day dose level of $C$. verum crude extract respectively when compared to cholesterol-fed rabbits.

\section{Effect of C. verum crude extract on triglyceride $(\mathrm{mg} / \mathrm{dl})$}

As shown in table 1, an increase of $529.42 \%$ was observed in serum triglyceride level when compared to control. The reduction of$63.50 \%$ and-68.03\% was observed in concurrent group III and IV respectively in comparison to athero diet fed rabbits (group II).

\section{Effect of C. verum crude extract on phospholipids (mg/dl)}

Atherodiet feeding for $120 \mathrm{~d}$ to control rabbits resulted in a significant elevation of $373.1 \%$ in phospholipids concentration as depicted in table 1. A significant decline $(\mathrm{P} \leq 0.001)$ was noticed inconcurrent treatment of $C$. verum crude extract with atherodiet to control rabbits (i.e. dose 200 $\mathrm{mg} / \mathrm{kg}$. b. wt./day reduction was $-56.63 \%$ and $300 \mathrm{mg} / \mathrm{kg}$. b. wt/day reduction was-61.23\%) when compared to group II animals.

\section{Effect of C. verum crude extract on serum LDL (mg/d)}

LDL cholesterol was significantly increased by 15.8 folds in rabbits, fed high-fat diet for $120 \mathrm{~d}$. (table 1) In contrast, as depicted in table 1 in the concurrent groups, LDL was- $68.80 \%$ lower at $200 \mathrm{mg}$ and$76.69 \%$ at $300 \mathrm{mg}$ dose level when compared with athero-diet fed rabbits (Group II).

\section{Effect of C. verum crude extract on serum VLDL (mg/dl)}

Cholesterol feeding resulted in an elevation by $530.07 \%$ in VLDLCholesterol levels in group II

When compared to control group. (table 1) On the other hand, as shown in table 1 concurrent feeding of $C$. verum inhibit the elevation by-63.08\% in $200 \mathrm{mg}$ and-68.08\% in $300 \mathrm{mg}$ dose levels in comparison to group II.

\section{Effect of C. verum crude extract on serum HDL (mg/dl)}

In athero fed rabbits, HDL cholesterol in comparison to total cholesterol was decreased, whereas it was again elevated after treatment with various doses of $C$. verum crude extract (table 1)

Table 1: Effect of methanolic extract of $C$. verum on serum biochemistry in rabbits

\begin{tabular}{|c|c|c|c|c|c|c|c|}
\hline \multirow[t]{2}{*}{ Identification } & \multirow[t]{2}{*}{ Group } & $\begin{array}{l}\text { Total } \\
\text { cholesterol }\end{array}$ & Triglyceride & phospholipid & $\begin{array}{l}\text { VLDL } \\
\text { chol. }\end{array}$ & LDL chol. & HDL chol. \\
\hline & & \multicolumn{6}{|l|}{$\mathrm{mg} / \mathrm{dl}$} \\
\hline \multirow{2}{*}{$\begin{array}{l}\text { Control(Placebo treated) from } \\
\text { day } 1-120\end{array}$} & \multirow[t]{2}{*}{ I } & 102.7 & 66.6 & \multirow[t]{2}{*}{$129.1 \pm 6.8$} & 13.3 & 46.8 & 42.6 \\
\hline & & \pm 9.8 & \pm 8.5 & & \pm 4.6 & \pm 8.2 & \pm 9.4 \\
\hline Atherodiet+Chol. feeding* from & II & $1014^{\mathrm{a}} \pm 17.9$ & $419.2^{\mathrm{a}} \pm 20.2$ & $610.8^{a} \pm 18.2$ & $83.8^{a}$ & $743.5^{\mathrm{a} \pm 14}$ & $186.7^{\mathrm{a}} \pm 17.9$ \\
\hline day $1-120$ & \% Deviation (I) & +887.34 & +529.42 & +373.12 & $\pm 8.5+530.07$ & $2+1488.6$ & +338.26 \\
\hline Atherodiet+Chol. feeding $+C$. & III & $362.5^{\mathrm{c}}$ & $153^{\mathrm{c}}$ & $264.9^{c}$ & $30.6^{c}$ & $107.03^{\mathrm{c}} \pm 4$ & $100^{c} \pm 2.1$ \\
\hline verum methanolic extract* from & \% Deviation (IIa) & \pm 15.8 & \pm 12.8 & \pm 13.6 & \pm 5.0 & 75 & -46.43 \\
\hline day 1-120 (Concurrent feeding & & -64.25 & -63.50 & -56.63 & -63.48 & -71.24 & \\
\hline Atherodiet+Chol. feeding $+C$ & IV & $287.6^{c} \pm 18.6$ & $134^{c}$ & $236.8^{c} \pm 13.6$ & $26.8^{\mathrm{c}}$ & $71.70^{\mathrm{c}}$ & $87.5^{\mathrm{c}}$ \\
\hline verum methanolic extract** & \% Deviation (IIa) & -71.63 & \pm 8.2 & -61.23 & \pm 2.8 & \pm 5.73 & \pm 4.6 \\
\hline $\begin{array}{l}\text { from day 1-120 (Concurrent } \\
\text { feeding) }\end{array}$ & & & -68.03 & & -68.01 & -80.73 & -53.13 \\
\hline
\end{tabular}

${ }^{*}$ Cholesterol feeding-500 mg/kg. b. wt in $5 \mathrm{ml}$ coconut oil/day, ${ }^{* *} C$. verum-200 mg/kg. b. wt./day, ${ }^{* * *} C$. verum-300 mg/kg. b. wt./day, values \pm 6 determination, a-P $\leq 0.01$ Significant Group II compared with Group I, b-P $\leq 0.01$ Significant Group III and IV compared with, c-P $\leq 0.001$ Highly Significant Group II, ns-non-significant. 


\section{Effect of C. verum crude extract on HDL ratio}

Fig. 1 illustrated that HDL ratio reduced significantly by-68.17\% in rabbits after $120 \mathrm{~d}$ atherodiet feeding in comparison with controls. Further HDL ratio significantly improved in a dose-dependent manner after concurrent administration of $C$. verum extract as indicated in fig. 1.

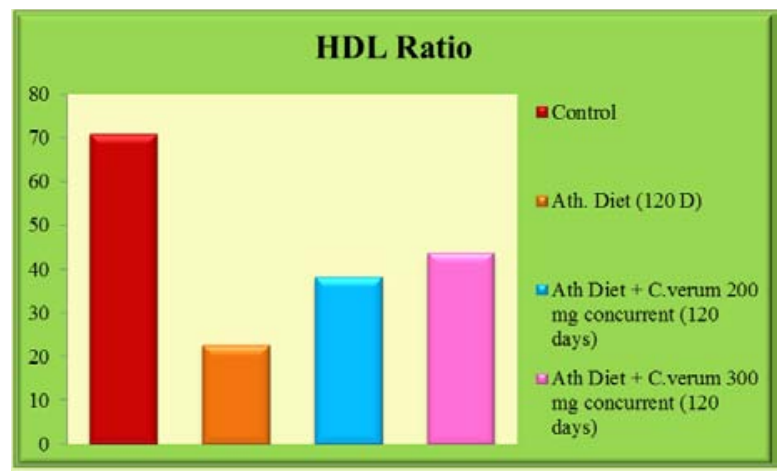

Fig. 1: Effect of $C$. verum crude extract on HDL ratio

\section{Effect of C. verum crude extract on atherogenic index}

A significant rise of $214.18 \%$ was observed in the atherogenic index after $120 \mathrm{~d}$ of athero diet feeding. An ameliorative action of plant extract on the atherogenic index (i. e- $40.85 \%$ at $200 \mathrm{mg}$ and- $48.53 \%$ at $300 \mathrm{mg}$ dose level of $C$. verum crude extract was observed in the concurrent group when compared with group II. (fig. 2)

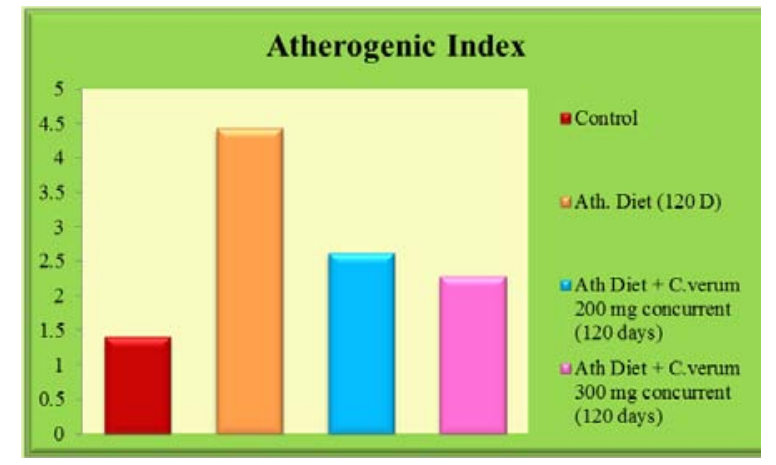

Fig. 2: Effect of $C$. verum crude extract on atherogenic index

\section{Histological observations}

The histopathological examinations were also performed in the ascending aorta and coronary artery in high cholesterol animal diet group and high cholesterol animal diet accompanied with $C$. verum extract group when compared with control (fig. 3-10).

\section{Asending Aorta}

Histological study showed that control group had completely normal arteries without any lesion in intima or media. In our study athero fed rabbits showed well developed atheromatous plaque protruding in to the lumen of the aorta. There were many foamy (lipid-laden) macrophages and dense fibrous tissue layer in the plaque could be seen. Media was also showing foam cell. The animals consuming the C. verum along with high cholesterol, the severity of lesions were significantly reduced, three layers of aortic wall were distinct, and only few lipid-laden cells were present in the medial layer when compared with the rabbits consuming the high cholesterol diet (group II) (fig. 3-6).

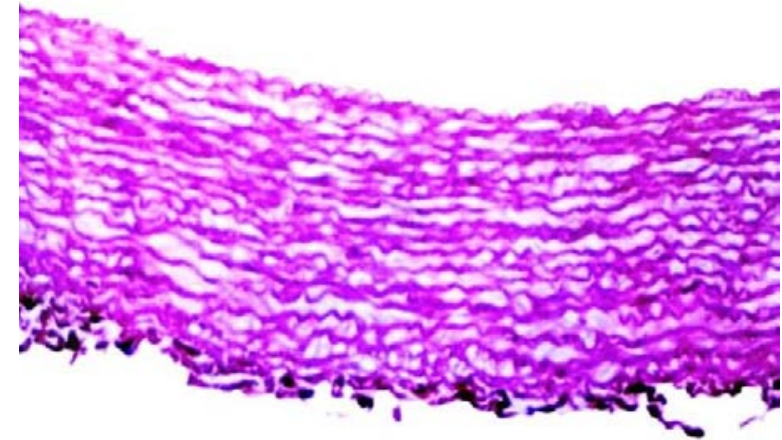

Fig. 3: Ascending aorta of control rabbit

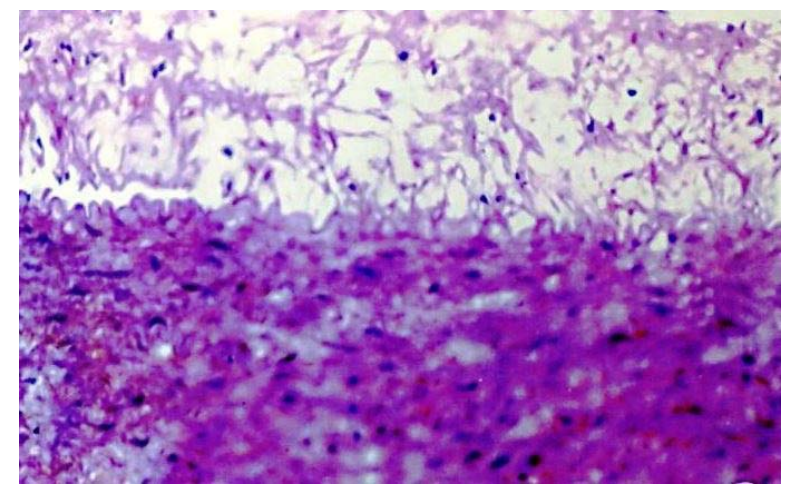

Fig. 4: Ascending aorta of rabbit after Athero diet feeding for $120 \mathrm{~d}$

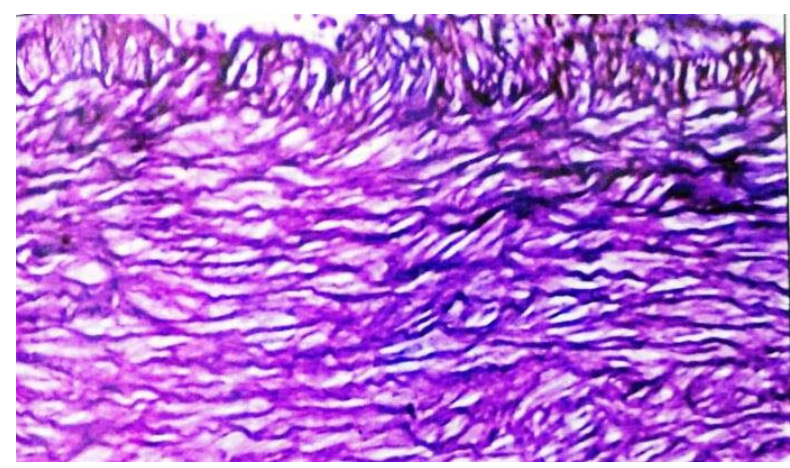

Fig. 5: Ascending aorta of rabbit-Athero Diet+C. verum $200 \mathrm{mg}$ concurrent (120 d)

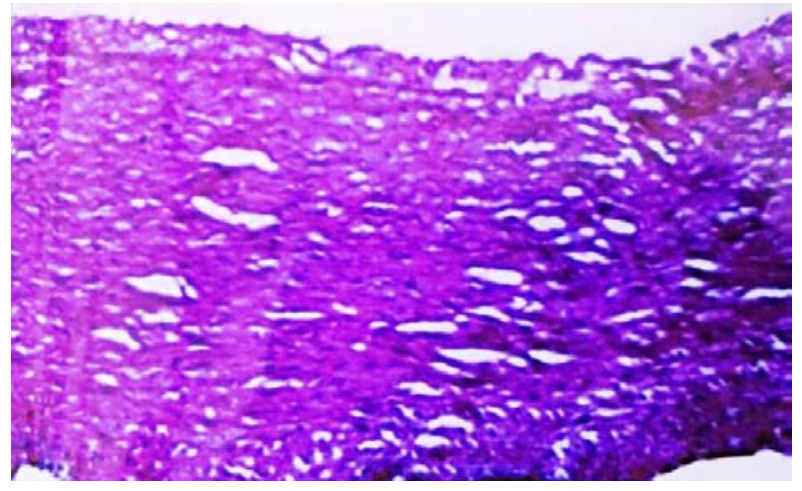

Fig. 6: Ascending aorta of rabbit-Athero Diet+C. verum $300 \mathrm{mg}$ concurrent (120 d) 


\section{Coronary artery}

The coronary artery of control group animals showed the lumen encircled by the arterial wall, which consisted of three distinct layers tunica intima, tunica media and tunica adventitia. The coronary arteries of hyper-cholesterolemic rabbits (Group II) showed foamy appearance, due to the presence of a large number of lipid-filled macrophages. The wall becomes very thick, reducing the size of the lumen. Our findings demonstrated that concurrent administration of C. verum extract with high cholesterol diet caused a significant increase in lumen size and thickening of tunica intima due to foam cell showed a reduction. However, the plaque has restricted to grow in concurrent groups, but coronary artery of low dose level treated group showed some fatty changes. (fig. 7-10)

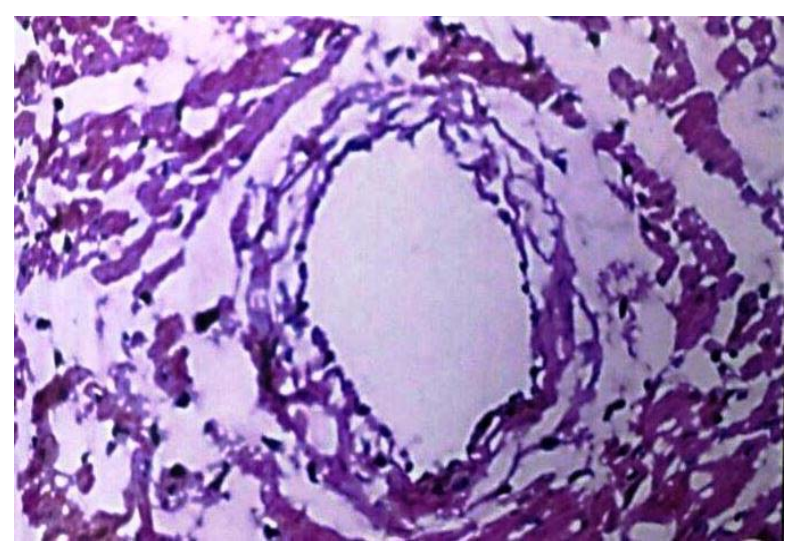

Fig. 7: Coronary artery of control rabbit

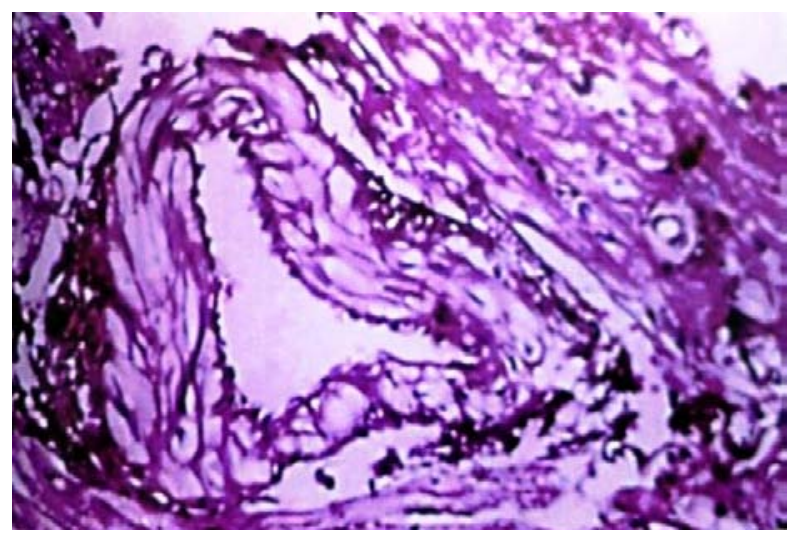

Fig. 8: Coronary artery of rabbit after Athero Diet feeding for $120 \mathrm{~d}$

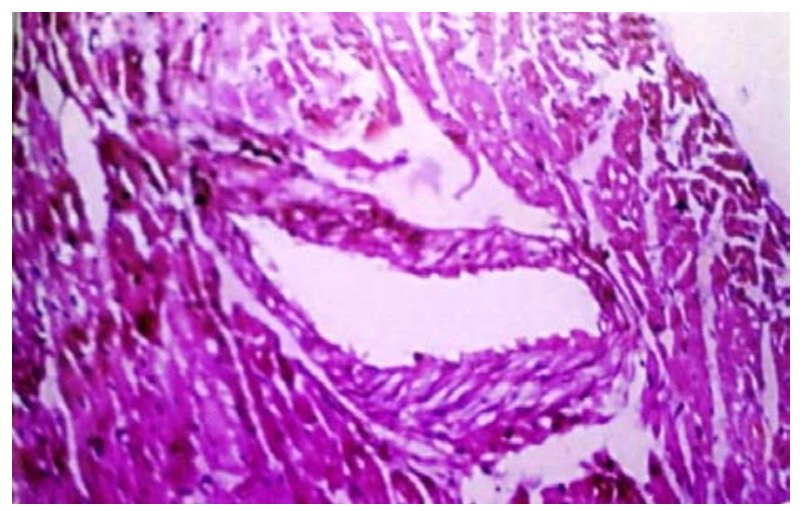

Fig. 9: Coronary artery of rabbit-Athero Diet+C. verum $200 \mathrm{mg}$ concurrent (120 d)

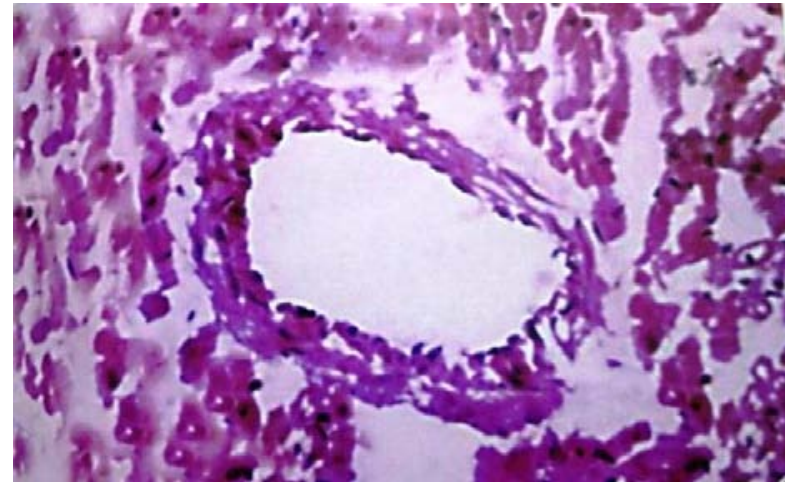

Fig. 10: Coronary artery of rabbit-Athero Diet+C. verum $300 \mathrm{mg}$ concurrent (120 d)

\section{DISCUSSION}

Findings of the current study recommended that administration with methanolic bark extract of $C$. verum significantly attenuated the elevated total cholesterol, triglyceride, phospholipid, lipoprotein cholesterol (HDL, LDL and VLDL) concentrations in high-fat-dietinduced hypercholesterolemic rabbits. A noticeable decrease was also observed in the atherogenic index and the HDL ratio improved significantly after supplementation with plant extract at a dose level of 200 and $300 \mathrm{mg} / \mathrm{kg} \mathrm{b.} \mathrm{wt/day.}$

A significant rise in serum cholesterol level after cholesterol feeding in rabbits were probably due to the overproduction of VLDL in the liver or by delayed catabolism of VLDL or both $[23,24]$. C. verum crude extract administration to hypercholesterolemic rabbits significantly decreased total cholesterol in serum. According to researchers, suggested mechanisms of cholesterol reduction by spices include; inhibition of intestinal absorption, up-regulation of the LDL-receptor and cholesterol $7 \alpha$-hydroxylase [25]. It is established that atherogenic diet elevates serum triglyceride levels basically by preventing its uptake and clearance by inhibiting catabolising enzymes like lipoprotein lipase (LPL) and lecithin cholesterol acetyltransferase (LCAT) [26]. Concurrent feeding of $C$. verum along with cholesterol significantly suppress the elevated blood concentration of TGs through increased expression and activity of lipoprotein lipase (LPL) and to decrease hepatic synthesis and secretion of triglycerides [27]. Pandey and Dubey, 2009 [28] also suggested that decline in TGs level may be due to inhibition of lipolysis so that fatty acid do not get converted into triglyceride.

The phospholipids level has shown a downward trend in the concurrent feeding of $C$. verum extract along with cholesterol treated animals. The reduction in phospholipids level possibly due to a higher level of phospholipase that metabolised the blood phospholipids in high cholesterol diet fed animals [29] which further confirms the significant protective effect of the plant extract against hypercholesterolemia.

Oxidative modification of LDL is one of the key steps in the development of atherosclerosis. The LDL-cholesterol lowering could result from an increased LDL metabolism and/or a reduced LDLsynthesis [30]. The ratio of LDL-C to HDL-C is also a protective indicator of cardiovascular disease incidence. The cholesterol induction produced a significant increase of this marker. The concurrent administration of methanolic extracts of $C$. verum provides a beneficial action on rabbit lipid metabolism with regard to the reduction of AI. Again, the methanolic extract of $C$. verum supplementation along with cholesterol concurrently cause marked improvement in the HDL ratio showing the beneficial effect of this plant in preventing atherosclerosis occurrence.

The coronary arteries of hypercholesterolemic rabbits were characterised by dense intimal fibrosis with necrotic debris lipidladen foam cells, cholesterol and calcium deposits. Since oxidation of cholesterol fractions (in particular LDL) has been accepted to play an important role in the atherosclerotic plaque formation process 
[31]. It has been proposed that extracts rich in antioxidant contents like cinnamon [32] may give beneficial results in this regard.

Plaque regression is defined as a decrease in the real intimal volume of a lesion as reflected by an increase in the luminal cross-sectional area [33]. There is evidence in animal models to indicate that regression can occur if serum cholesterol and other lipids are reduced to normal size [34]. The inhibition of atherosclerotic plaque formation by $C$. verum might be mediated by its improvement of antioxidation status, lipid metabolism and anti-inflammation response. The spice principles like eugenol, cinnamaldehyde, cinnamic acid, cineol have been shown to inhibit human polymorphonuclear leucocytes 5-lipoxygenase activity, the key enzyme involved in leukotriene synthesis, which can reduce the production of inflammatory mediators [35]. In the Concurrent $C$. verum extract, group plaques were decreased significantly compared to the high-cholesterol diet group.

The methanol bark extract contains tannins, flavonoids, glycosides, terpenoids, coumarins and anthraquinones [36]. Cinnamon has been shown to contain trans-cinnamic acid and trans-cinnamaldehyde [37] and their derivatives which show better antioxidant activities. The total phenolic content in cinnamon bark extract is $(220.5 \pm 0.53)$ milligrams of gallic acid equivalent (GAE) per gram of samples contributes significantly for its antioxidant activity [38, 39]. Flavonoids protect alpha-tocopherol and plausibly other antioxidants against oxidation [40].

The anti-hypercholesterolemic effect of flavonoids is related to decline of 3-hydroxy-3-methylglutaryl coenzyme An (HMG CoA) and decrease in apo-B secretion in hepatocytes [41]. The tannins and flavones may act as in free radical scavenging mechanism and may prevent atherogenesis in rabbit aorta. While the plant sterols may interact with the intestinal absorption of fats and cholesterols [42].

The essential oils were reported to show strong antioxidant activity using in vitro models [43]. Lee et al. 2003 [44] found cinnamate, a phenolic compound in cinnamon bark, to significantly lower hepatic cholesterol and triglyceride levels in rats fed high cholesterol diet. Berberine (BBR), an alkaloid isolated from the Chinese herb huanglian, upregulates hepatic LDLR expression by extending the half-life of LDLR mRNA without affecting gene transcription [45]. It is possible that the presence of alkaloids in methanolic bark extract may possess LDLR mRNA stabilisation property and stimulating effect on hepatic LDLR expression.

Regarding observed outcomes, the possible mechanism could be the presence of biologically active phytoconstituents such as phytosterols, fats, alkaloids, flavonoids, phenols, terpenoids, carbohydrates, proteins and tannins in the methanolic extract of $C$. verum that may demonstrate the multitarget, multicomponent features for regulating lipid metabolism [46]. Thus the isolation of the pure secondary metabolites responsible for the extracts activity and their molecular mechanism as well as expression studies related to lipid metabolism will be a good addition to the cinnamon literature.

\section{CONCLUSION}

In accordance with these results, it may be confirmed that consumption of $C$. verum extract could prevent or be helpful in reducing the complications of dyslipidemia associated with oxidative stress. Antiatherosclerotic and lipid lowering activities of this plant are probably due to its phytochemicals identified in cinnamon. In conclusion, methanolic extract of $C$. verum seems to be a potential cardio protective candidate in rabbits. Advance studies need to be done in order to establish a detailed assessment of metabolic effects and antioxidant actions of cinnamon.

\section{ACKNOWLEDGEMENT}

Authors are grateful to Department of Zoology, University of Rajasthan, Jaipur (India) for providing necessary facilities.

\section{CONFLICT OF INTERESTS}

The authors report no declarations of interest

\section{REFERENCES}

1. Roger VL, Go AS, Lloyd-Jones DM, Benjamin EJ, Berry JD, Borden $\mathrm{WB}$, et al. Heart disease and stroke statistics2012update: a report from the American Heart Association. Circulation Adv Appl Sci Res 2011;2:440-50.

2. Harrison D, Kathy KG, Hornig B, Drexler H. Role of oxidative stress in atherosclerosis. Am J Cardiol 2003;91:7A-11A.

3. Bibave KH, Shenoy PA, Mahamuni SP, Bandawane DD, Nipate SS, Chaudhari PD. Preclinical evaluation methods for screening of anti-atherosclerotic drugs: an overview. Asian J Biomed Pharm Sci 2011;1:1-14.

4. Harauma A, Murayama T, Ikeyama K, Sano H, Arai H, Takano $\mathrm{R}$, et al. Mulberry leaf powder prevents atherosclerosis in apolipoprotein E-deficient mice. Biochem Biophys Res Commun 2007;358:751-6.

5. Niki E. Antioxidants and atherosclerosis. Biochem Soc Trans 2004;32:156-9.

6. Mahmood ZA, Sualeh M, Mahmood SBZ, Karim MA. Herbal treatment for cardiovascular disease: the evidence-based therapy. Pak J Pharm Sci 2010;23:119-24.

7. Tasawar Z, Siraj Z, Ahmad N, Lashari ML. The effects of Nigella sativa (Kalonji) on lipid profile in patients with stable coronary artery disease in Multan, Pakistan. Pak J Nutr 2011;10:162-7.

8. Tanabe H, Yoshida M, Tomita N. Comparison of the antioxidant activities of 22 commonly used culinary herbs and spices on the lipid oxidation of pork meat. Anim Sci J 2002;73:389-93.

9. Vangalapati M, Sree Satya N, Surya Prakash DV, Avanigadda S. A review on pharmacological activities and clinical effects of cinnamon species. Res J Pharm Biol Chem Sci 2012;3:653-63.

10. Joshi K, Awte S, Bhatnagar P, Walunj S, Gupta R, Joshi S, et al. Cinnamomum zeylanicum extract inhibits proinflammatory cytokine TNF $\mu$ : in vitro and in vivo studies. Res Pharm Biotechnol 2010;2:14-21.

11. El-Baroty GS, Abd El-Baky HH, Farag RS, Saleh MA. Characterization of antioxidant and antimicrobial compounds of cinnamon and ginger essential oils. Afri J Biochem Res 2010;4:167-74.

12. Aggarwal BB. Targeting inflammation-induced obesity and metabolic diseases by curcumin and other nutraceuticals. Annu Rev Nutr 2010;30:173-99.

13. Gupta C, Garg AP, Uniyal RC, Kumari A. Comparative analysis of the antimicrobial activity of cinnamon oil and cinnamon extract on some food-borne microbes. Afri J Microbiol Res 2008;2:247-51.

14. Koppikar SJ, Choudari AS, Snehal A, Vansi S, Kumari S, Chattopadhyay S, et al. BMC Cancer 2010;10:1471-2407.

15. Buyukbalci A, El SN. Determination of In vitro antidiabetic effects, antioxidant activities and phenol contents of some herbal teas. Plant Foods Hum Nutr 2008;63:27-33.

16. Zlatkis A, Zak B, Boyle AJ. A method for the determination of serum cholesterol. J Lab Clin Med 1953;41:486-92.

17. Gottfried SP, Rosenburg B. Improved manual spectrophotometric procedure for determination of serum triglycerides. Clin Chem 1973;19:1077-8.

18. Zilversmit DB, Davis AK. Microdetermination of plasma phospholipids by trichloroacetic acid precipitation. J Lab Clin Invest 1950;35:155-60.

19. Burnstein M, Scholnic MR, Martin R. Rapid method of isolation of lipoprotein from human serum by precipitation of polyamines. J Lipid Res 1970;11:583-7.

20. Friedwald WI, Levy RI, Freidrickson DS. Estimation of concentration of LDL-cholesterol in plasma without preparative of ultra-centrifuge. Clin Chem 1972;28:449-502.

21. Lowry OH, Rosenburg NJ, Jarr AL, Roudall R. Protein measurement with Folin-phenol reagent. J Biol Chem 1951;193:265-75.

22. Hjermann I, Enger SC, Helgeland A, Holme I, Leren P, Trygg K. The effects of dietary changes on high density lipoprotein cholesterol. The oslo study. Am J Med 1979;66:105-9.

23. Chapman MJ, Caslake M, Packard C, McTaggart F. New dimension of statin action on apo-B atherogenicity. Clin Cardiol 2003;26(1 Suppl 1):I-7-10.

24. Wehinger A, Tancevski I, Schgoer W, Eller P, Hochegger K, Morak $\mathrm{M}$, et al. Phospholipid transfer protein augments in THP-1- 
derived macrophages induced by lipolyzed hypertriglyceridemic plasma. Arterioscler Thromb Vasc Biol 2007;27:908-14.

25. Mahesh T, Sri Balasubashini MM, Menon VP. Photo-irradiated curcumin supplementation in streptozotocin-induced diabetic rats: effect on lipid peroxidation. Therapie 2004;59:639-44.

26. Maruthappan VG, Shree KS. Blood cholesterol lowering effect of Adenanthera pavonina seed extract on atherogenic diet induced hyperlipidaemia rats. Int J Pharm Sci Res 2010;1:87-94.

27. Anderson JW. Whole grains protect against atherosclerotic cardiovascular disease. Proc Nutr Soc 2003;62:135-42.

28. Pande VV, Dubey S. Antihyperlipidemic activity of Sphaeranthus indicus on atherogenic diet induced hyperlipidemia in rats. Int J Green Pharm 2009;3:159-61.

29. Adaramoye OA, Nwaneri VO, Anyanwu KC, Farombi EO, Emerole GO. Possible anti-atherogenic effect of Kolaviron (a Garcinia kola seed extract) in hypercholesterolemic rats. Clin Exp Pharmacol Physiol 2005;32:40-6.

30. Latha M, Pari L. Antihyperlipidaemic effect of aqueous extract of Scoparia dulcis in albino rats treated with Streptozotocin. J Herbs Spices Med Plants 2005;11:59-66.

31. Durak I, Ozturk HS, Oclay E, Guven C. Effects of garlic extract supplementation on blood lipid and antioxidant parameters and atherosclerotic plaque formation process in cholesterolfed rabbits. J Herbal Pharmacol 2002;2:19-32.

32. Dragland S, Senoo H, Wake K, Holte K, Blomhoff R. Human nutrition and metabolism: Several culinary and medicinal herbs are important sources of dietary antioxidants. J Nutr 2003;133:1286-90.

33. Accad M, Smith SJ, Newland DL, Sanan DA, King LE Jr, Linton $\mathrm{MF}$, et al. Massive xanthomatosis and altered composition of atherosclerotic lesions in hyperlipidemic mice lacking acyl CoA cholesterol acyltransferase1. J Clin Invest 2000;105:711-9.

34. Libby P. Changing concepts of atherogenesis. J Intern Med 2000;247:349-58.

35. Prasad NS, Raghavendra R, Lokesh BR, Naidu KA. Spice phenolics inhibit human PMNL 5-lipoxygenase. Prostaglandins Leukotrienes Essent Fatty Acids 2004;70:521-8.

36. Shihabudeen HMS, Priscilla DH, Thirumurugan K. Cinnamon extract inhibits $\alpha$-glucosidase activity and dampens postprandial glucose excursion in diabetic rats. Nutr Metab (Lond) 2011;8:46.
37. Rao PV, Gan SH. Cinnamon: a multifaceted medicinal plant. J Evidence-Based Complementary Altern Med 2014: http:// dx.doi.org/10.1155/2014/642942

38. Rakshit M, Ramalingam C. In vitro antibacterial and antioxidant activity of Cinnamomum verum (Cinnamon) aqueous bark extract in reference to its total phenol content as a natural preservative to food. Int J Biol Biotechnol 2011;8:539-42.

39. Rezaeizadeh A, Zuki ABZ, Abdollahi M, Goh YM, Noordin MM, Hamid $\mathrm{M}$, et al. Determination of antioxidant activity in methanolic and chloroformic extracts of Momordica charantia. Afr J Biotechnol 2011;10:4932-40.

40. Yu SG, Thomas AM, Gapor A, Tan B, Qureshi N, Qureshi AA. Doseresponse impact of various tocotrienols on serum lipid parameters in 5-week-old female chickens. Lipids 2006;41:453-61.

41. Borradaile NM, de Dreu LE, Barrett PH, Huff MW. Inhibition of hepatocyte apo-B secretion by naringenin: Enhanced rapid intracellular degradation independent of reduced microsomal cholesteryl esters. J Lipid Res 2002;43:1544-54.

42. Katan MB, Grundy SM, Jones P, Law M, Miettinen T, Paoletti R, et al. Efficacy and safety of plant stanols and sterols in the management of blood cholesterol levels. Mayo Clin Proc 2003;78:965-78.

43. Jayaprakasha GK, Jagan Mohan Rao L, Sakariah KK. Volatile constituents from Cinnamomum zeylanicum fruit stalks and their antioxidant activities. J Agric Food Chem 2003;51:4344-8.

44. Lee JS, Jeon SM, Park EM, Huh TL, Kwon OS, Lee MK, et al. Cinnamate supplementation enhances hepatic lipid metabolism and antioxidant defense systems in high cholesterol-fed rats. J Med Food 2003;6:183-91.

45. Abidi P, Zhou Y, Jiang JD, Liu J. ERK-dependent regulation of hepatic LDL receptor expression by herbal medicine berberine. Arterioscler Thromb Vasc Biol 2005;25:2170-6.

46. Bei WJ, Guo J, Wu HY, Cao Y. Lipid-regulating effect of traditional chinese medicine: mechanisms of actions. J Evidence-Based Complementary Altern Med 2012. http:// dx.doi.org/10.1155/2012/970635

\section{How to cite this article}

- $\quad$ Suresh C Joshi, Pratibha K Jain, Priyanka Sharma. Antiatherosclerotic and lipid-lowering effects of Cinnamomum verum in cholesterol-fed rabbits. Int J Curr Pharm Res 2017;9(1):75-80. 